\title{
A Tutela Preventiva das Liberdades: Habeas-Corpus e Mandado de Segurança
}

\author{
Ada Pellegrini Grinover \\ Professora Titular de Direito Processual Penal \\ da Faculdade de Direito da Universidade
São Paulo
}

\begin{abstract}
SumÁrio: 1. A tutela jurisdicional das liberdades; 2. Tutela repressiva e tutela preventiva; 3. A tutela preventiva no ordenamento brasileiro; 4. Habeas-corpus; 5. Mandado de segurança; 6. Habeas-corpus preventivo; 7. Mandado de segurança preventivo.
\end{abstract}

1 - Direitos do homem, Direitos fundamentais, Liberdades públicas, Direitos da personalidade, Direitos públicos subjetivos: expressões diversas para indicar a mesma categoria de direitos, embora distinta segundo a perspectiva adotada por orientações jurídicas as mais variadas. E, no âmbito dos denominados Grundrechte, a particular espécie, de conteúdo negativo, dos Abwehrrechte, ou direitos de defesa.

Mas esses direitos ou liberdades, de caráter declaratório, só se completam na medida em que lhes correspondam instrumentos adequados de tutela, com conteúdo de garantia. E a garantia, posta como tutela do direito, pode operar nos mais diversos sistemas de proteção: o sistema jurisdicional, o sistema administrativo, o sistema político, os sistemas mistos.

De há muito, e em todo lugar, sustenta-se que o sistema mais eficiente de tutela das liberdades é o jurisdicional, quer pela independência e a imparcialidade do órgão a que a função é atribuída, quer pelos instrumentos organizados de tutela de que dispõe. Instrumentos organizados (vale dizer, procedimentos legais, de contornos definidos, com objeto específico e dirigidos a órgãos determinados), que permitem ao indivíduo ou ao grupo social estabelecer e assegurar as liberdades violadas ou ameaçadas, perante os tribunais, mediante o due process of law. 
Trata-se daquela que, com feliz expressão, foi denominada jurisdição constitucional das liberdades, ${ }^{1}$ a sublinhar a inolvidável advertência de CALAMANDREI: "todas as liberdades são vãs, se não puderem ser reivindicadas e defendidas em juízo" ${ }^{2}$.

2 - Mas a tutela processual pode revestir-se de duas modalidades: a repressiva, ou sucessiva, e a preventiva. A primeira, sem dúvida a mais comum, opera a posteriori, com a finalidade de eliminar o prejuízo produzido pela lesão do direito; a segunda opera a priori, com o objetivo de evitar o dano que deriva da ameaça de lesão a um direito, antes que esta se consume ${ }^{3}$. Foi justamente salientado que, na tutela preventiva, o interesse de agir não decorre do prejuízo, mas do perigo de prejuízo jurídico ${ }^{4}$ : em outras palavras, da ameaça de lesão ou, mais precisamente, frente a sinais inequívocos de sua iminência.

Não se devem confundir tutela preventiva e tutela cautelar: conceitos distintos, como observou CALAMANDREI, conquanto relacionados como gênero e espécie ${ }^{5}$. A tutela ordinária preventiva visa diretamente à proteção da situação material: por isso - escreveu BARBoSA MOREIRA ${ }^{6}$ - o provimento jurisdicional descansará no prévio acertamento do direito e jamais assumirá feição de provisoriedade, ao mesmo tempo em que o processo só será instrumental no sentido genérico em que todo o processo o é. A tutela cautelar, ao contrário, visa

1. CAPPELLETti, La giurisdizione costituzionale delle libertà, 1955.

2. Calamandrei, Processo e giustizia, em Riv. dir. proc., 1950, I, pág. 289. DRAN (Le contrôle juridictionnel et la garantie des libertés publiques, 1968) assim se expressa: “Il n'y a liberté publique que lorsque les particuliers disposent de voies de droit leur permettant, en cas de méconnaissance, de les faire respecter; il faut donc leur donner les moyens d'en faire sanctionner les atteintes, sous peine de voir la liberté demeurer une simple virtualité, une faculté. Ces moyens, ces voies de droit, ce sont les sanctions juridictionnelles, fruit du contrôle exercé par le juge", Cf, entre nós, RAO, o direito e a vida dos direitos, vol. II, 1958, pág. 410; Ferreirá Filho, Grinover e Cunha Ferraz, Liberdades públicas, 1978, pág. 321.

3. Calamandrei, Introduzione allo studio sistematico dei provvedimenti cautelari, 1936, pág. 16. A mesma terminologia é utilizada por ConigLio (Il sequestro giudiziario e conservativo, 1926, pág. 207 e segs.), DINI (I provvedimenti d'urgenza nel diritto processuale civile, 1973, pág. 18 e segs.) e Proto Pisani (Appunti preliminarira diritto sostanziale e processo, em Diritto e giurisprudenza, vol. 93,1978, n. 1).

4. Calamandrei, op. e loc. cit.

5. ID., ibid., Cf. MrCHeli, L'azione preventiva, em Riv. dir. proc., 1959, pág. 201 e segs., especialmente pág. 221.

6. Barbosa Moreira, Tutela sancionatória e tutela preventiva, em Rev. Inst. Adv. Paraná, n. 1, 1979, pág. 91. 
a assegurar imediatamente a eficácia do próprio processo, protegendo o direito substancial apenas indiretamente. Somente neste emerge a dupla instrumentalidade, a instrumentalidade "ao quadrado", magistralmente delineada por CALAMANDREI ${ }^{7}$ A tutela cautelar leva a um provimento sempre provisório; a tutela preventiva, a um provimento definitivo ${ }^{8}$.

A superioridade da tutela preventiva foi recentemente assinalada, frente à inviabilidade freqüente da modalidade tradicional de tutela que consiste na aplicação de sanções, quer sob a forma primária da restituição ao estado anterior, quer sob as formas secundárias da reparação ou do ressarcimento ${ }^{\text {. }}$. $\mathrm{E}$ a gravidade do problema, afirmou-se, aumenta de intensidade, quando se passa das relações jurídicas de caráter patrimonial àquelas categorias em que se reconhece ao homem uma situação de vantagem insuscetível de traduzir-se em termos econômicos: os direitos da personalidade. É verdade que o poder geral de cautela pode, ao menos provisoriamente, suprir a ausência de formas idôneas de tutela preventiva. Mas, observou-se também, a tutela cautelar é insitamente instável; de outro lado, leva a um desdobramento inútil de processo, quando a rigor um só seria suficiente; e, finalmente, porque se daria a título de cautela aquilo que se poderia dar sob a forma de prestação jurisdicional satisfativa? ${ }^{10}$

Foi por razões como essas que o Congresso Internacional de Direito Comparado, realizado em Bruxelas em 1958, já aprovara, unanimemente, uma declaração favorável à instituição de um "juízo preventivo geral" em todos os países ${ }^{11}$.

Tudo isto reconduz, em última análise, à lição clássica de Chiovenda, nunca suficientemente lembrada: "La necessità di

7. CaLAMANDREI, Introduzione cit., pág. 21/22.

8. CARNelutTi contrapôs o processo cautelar ao processo definitivo (Lezioni di diritto processuale civile, II, 1926, pág. 109 e segs.), embora em outras obras preferisse, ao termo "definitivo", o de "satisfativo" (Carattere della sentenza di fallimento, em Riv. dir. proc. civ., vol. VIII, 1931, pág. 171). 9. Barbosa Moreira, op. cit., pág. 86 e segs., especialmente pág. 90. 10. ID., op. cit., pág. 93.

11. É o seguinte o texto da declaração: "Il est désiderable que dans chaque pays existe la possibilité de s'adresser aux tribunaux non seulement en cas de violation déjà accomplie d'un droit ou d'un interêt juridique, mais aussi, avec les garanties convenables, lorsqu'il s'agit de prévenir une telle violation en cas de menace objective et actuelle. Cette protection peut être obtenue, selon le cas, soit par un jugement déclaratoire ou préventif. Il est désiderable, en outre, que toutes mesures provisoires puissent être ordonnées, au besoin, même en vue d'une contestation future": apud Micheli, op. cit., pág. 222, nota. 
servirsi del processo per ottener ragione non deve tornar a danno di chi ha ragione" 12.

3 - No campo das relações jurídicas de direito privado, o ordenamento brasileiro só conhece dois casos típicos de tutela preventiva ${ }^{13}$. O primeiro, o interdito proibitório, protege "o possuidor direto ou indireto, que tenha justo receio de ser molestado em sua posse", e que "poderá impetrar ao juiz que o segure da turbação ou esbulho iminente, mediante mandado proibitório em que comine ao réu determinada pena pecuniária, caso transgrida o preceito" (art. $932 \mathrm{CPC}$ ). O segundo, a nunciação de obra nova, compete: "I - ao proprietário ou possuidor, a fim de impedir que a edificação de obra nova em imóvel vizinho lhe prejudique o prédio, suas servidões ou fins a que é destinado; II - ao condômino, para impedir que o co-proprietário execute alguma obra com prejuízo ou alteração da coisa comum; III - ao Município, a fim de impedir que o particular construa em contravenção da lei, do regulamento ou da postura" (art. $934 \mathrm{CPC}$ ), tudo sob cominação de pena para o caso de inobservância do preceito (art. 936, II, CPC). Observou-se, porém, que, exceto quanto ao último caso de nunciação de obra nova (art. 934, III, CPC), a tutela preventiva, mediante procedimento especial, fica ordenada exclusivamente à proteção da posse e da propriedade, deixando a descoberto os direitos não patrimoniais e os denominados interesses difusos ${ }^{15}$.

Além dos dois casos acima apontados, costuma-se indicar, como pertencente à tutela preventiva, a ação meramente declaratória ${ }^{16}$. Mas aqui é necessário distinguir: não se pode falar em tutela preventiva quando a ação meramente declaratória for usada após a consumação do dano, como hoje o ordenamento pátrio expressamente permite, no art. $4 .{ }^{\circ} \mathrm{CPC}{ }^{17}$. Usada

12. Chiovenda, Istituzioni di diritto processuale civile, vol. I, 1933, pág. 147 .

13. O código processual civil de 1939 falava em "medidas preventivas" nos arts. 675 a 688 , referindo-se às medidas cautelares. As "medidas preventivas" do código revogado compõem o Livro III do estatuto processual vigente, sob o título "Do processo cautelar" (arts. 796 a 889).

15. Barbosa Moreira, op. cit., pág. 93.

16. Sobre a possibilidade de classificar as ações segundo a natureza do provimento invocado, mesmo na teoria abstrada da ação v. Cintra, Grinover \& Dinamarco, Teoria geral do processo, $3 .^{a}$ ed., 1981, pág. 232 e segs.

17. Muito discutida é a posição do código, no sentido de admitir a ação meramente declaratória sobre o direito já exigível. Para uma resenha doutrinária, v. BARBI, Comentários ao $\mathrm{CPC}$, vol. I, tomo I, 1975, n. 65 . 
antes do prejuízo, a ação meramente declaratória exercerá funçấ preventiva, na medida em que a parte vencida obedeça voluntariamente ao preceito, sem obrigar o vencedor a intentar outra ação condenatória: nesta hipótese, o meio de intimidação, e de coerção, seria bastante fraco ${ }^{18}$.

Outros casos de tutela preventiva foram indicados pela doutrina como reconduzíveis à condenação para o futuro ${ }^{19}$, sobre a qual escreveu magistralmente RoGNONI ${ }^{20}$ : assim, quanto às relações jurídicas sujeitas a condição ou a termo (art. $572 \mathrm{CPC}$ ), às obrigações de não fazer (art. $287 \mathrm{CPC}$ ) e às prestações periódicas vincendas (art. $290 \mathrm{CPC}$ ). Mas o sistema brasileiro não prevê, em termos gerais, um pedido de condenação para o futuro como o existente na ZPO alemã (§ 259). $\mathrm{E}$, quanto à ação cominatória, prevista no art. $287 \mathrm{CPC}$, houve uma degradação da tutela preventiva, porquanto o código de 1939 dispunha que, após o conhecimento sumário e provisório, o juiz ordenasse ao devedor que se abstivesse do ato proibido, ou que se praticasse o ato devido, sob ameaça de pena para o caso de descumprimento da obrigação (e não da sentença, como hoje se prevê) ${ }^{21}$.

Muito mais interessante é o repertório brasileiro, quando se passa à tutela preventiva das relações jurídicas de direito público. Os instrumentos processuais específicos de que o sistema dispóe para a tutela das liberdaúes são a ação popular constitucional, o habeas-corpus e o mandado de segurança.

Mas na realidade a ação popular não é instrumento de garantia das liberdades, senão na medida em que protege, em última análise, o direito democrático de participação do cidadão na vida pública ${ }^{22}$. Sempre de caráter corretivo, visando a invalidar o ato da administração pública, a ação popular deflui do art. 153, § 31, da Constituição, sendo, em si mesma, um direito político e, contemporaneamente, uma garantia político-constitucional do cidadão: ao interesse pessoal do autor popular (uti cives), acresce o interesse da coletividade. $\mathrm{E}$ assim, a ação popular é o instrumento posto à disposição do indivíduo

18. Barbosa Moreira, op. cit., pág. 94.

19. Barbosa Moreira, op. e loc. cit.; Calmon de Passos, Comentários ao $\mathrm{CPC}$, vol. III, $2 .^{\mathfrak{a}}$ ed., 1977 , pág. 257 e segs.

20. RogNONI, La condanna in futuro, 1958.

21. Certa tendência jurisprudencial, já sob a égide do código de 1939, entendia que a multa só começaria a incidir depois do trânsito em julgado da sentença, desaguando, assim, na linha adotada pelo código em vigor: v. Barbosa Moreira, op. cit., pág. 95/96.

22. Ferreira filho, Grinover \& Cunha Ferraz, op. cit., pág. 475. 
para a defesa dos princípios da legalidade e da probidade administrativa ${ }^{23}$.

Não nos deteremos, portanto, na tutela preventiva que a ação popular pode exercer. Basta recordar que a ação pode ser ativada antes que ocorra o prejuízo ao bem "de valor econômico, artístico, estético, histórico ou turístico" (Lei n. 4.717 , de 29 de junho de 1965 , art. $1 .^{\circ}, \S 1 .^{\circ}$, na redação que lhe foi dada pelo art. 33 da Lei n. 6.513, de 20 de dezembro de 1977) e que se permite a prevenção da lesão mediante a suspensão liminar dos efeitos do ato administrativo impugnado (art. 5. ${ }^{\circ}$, § $4 .^{\circ}$, da Lei 4.717 , de 1965 , introduzido pelo art. 34 da Lei n. 6.513, de 1977).

Passemos, desde logo, ao habeas-corpus e ao mandado de segurança.

4 - O habeas-corpus brasileiro, como se sabe, encontra seus antecedentes diretos no direito romano, no direito inglês e no direito português da idade média. Do direito romano, e mais exatamente do interdictum de libero homine exhibendo, retirou a garantia criminal preventiva, que então consistia na ordem do pretor para que se lhe apresentasse a pessoa, livre de qualquer constrição, para ser interrogada e encarcerada, só se a prisão fosse justa. Também a Magna Carta de 1215, no art. $3 .^{\circ}$, não tolerava a prisão dos barões sem o julgamento de seus pares, correspondendo, assim, a uma medida preventiva. Quanto ao Bill of Rights, de 1628, se bem que, introduzindo formalmente o habeas-corpus, mantivesse a garantia da Magna Carta, não se aplicava, na interpretação dos tribunais, aos casos de prisão ilegal, principalmente quando a ordem proviesse do monarca (exceto per speciale mandatum regis).

Do Habeas Corpus Act de 1679 - que assegurou a tutela em todos os casos de acusação criminal, mas não em caráter preventivo -, o Brasil retirou a garantia a posteriori. Preventiva era, ao invés, a tutela disposta nas Cartas de Seguro das Ordenações do Reino, como faculdade atribuída ao acusado de comparecer a juízo impunemente e, sob certas condições, de voltar em liberdade (Ord. Afonsinas, T. LVII do L. V; Ord. Manuelinas, T. XLIV do L. V; Ord. Filipinas, T. CXXIX do L. V).

A primeira Constituição brasileira - a Constituição imperial de 1824 - não abrigou expressamente o instituto, indire-

23. Id., ibid., pág. 477/478, onde também se salienta a finalidade da ação popular, sob aspecto semelhante ao do recall e do veto popular. 
tamente previsto no art. 179, VIII. Foi o Código Criminal de 1830 que delineou o habeas-corpus, regulado, na modalidade repressiva, pelo Código de Processo Criminal de 1832, no art. 340. Somente em 1871, pela Lei n. 2.033, de 20 de setembro, o habeas-corpus foi estendido aos estrangeiros e ampliado a dimensão preventiva, para os casos de ameaça. Foi assim que o ordenamento brasileiro conferiu ao writ o caráter preventivo, que não tinha sequer no direito inglês.

O remédio foi elevado à categoria constitucional pela Constituição republicana de 1891, no art. 72 , § 22. E a ampla fórmula constitucional - prevendo as modalidades preventiva e repressiva - autorizou o entendimento segundo o qual o remédio brasileiro seria mais extenso do que o modelo anglo-saxônico. Argumentando com o princípio ubi ius, ibi remedium, a doutrina iniciou a obra de construção jurídica que acabaria levando à instituição do mandado de segurança. É por demais conhecida a engenhosa teoria da posse dos direitos pessoais, que acabou prevalecendo no Supremo Tribunal Federal o qual, em 1909, estendeu o habeas-corpus a casos de natureza não penal, para a proteção de qualquer direito que tivesse como pressuposto de exercício a liberdade de locomoção.

Mas uma writ de contornos tão amplos encontraria muita resistência. E a reforma constitucional de 1926 reconduziu o instituto a seu leito clássico, na nova redação do art. 72 , § 22 da Constituição, que restringia o remédio à liberdade pessoal, nas modalidades sucessiva e preventiva.

A engenhosidade dos juristas da época pôs-se imediatamente à obra para criar um novo instituto que cobrisse a área deixada a descoberto pelo habeas-corpus. Mas as circunstâncias políticas do momento impediriam a introdução do novo instrumento de tutela até a Constituição de 1934. A partir daí, habeas-corpus e mandado de segurança seriam mantidos, lado a lado, com duas exceções: a Constituição estadonovista de 1937 e o Ato Institucional n. 5, de 13 de dezembro de 1968; a primeira, omitindo o mandado de segurança, mantido apenas a nível de lei ordinária; o segundo, suspendendo a garantia do habeas-corpus para os crimes políticos, os crimes contra a segurança nacional, a ordem econômica e social e a economia popular.

No direito vigente, o habeas-corpus é constitucionalmente regulado pelo art. $153, \S 20$. Da Constituição retiram-se os seus requisitos essenciais: protege exclusivamente a liberdade de 
locomoção; a ordem é concedida frente a um ato ilegal; a ilegalidade pode ser cometida pela administração pública ou por particulares; pode ser obtido em favor de todos; pode ser impetrado por qualquer pessoa, independentemente de capacidade postulatória; é previsto na modalidade sucessiva e na preventiva; é excluído nas transgressões disciplinares.

O Código de Processo Penal vigente ocupa-se do habeas-corpus no art. 647 e segs. Embora o inclua entre os recursos, a doutrina moderna atribui-lhe natureza jurídica de ação ${ }^{24}$. 0 art. 648 enumera os casos de "coação ilegal", deles defluindo a possibilidade de obter-se a ordem não somente nos casos de prisão, mas também quando se instaure contra o acusado inquérito policial ou ação penal a que falte o requisito do fumus boni iuris, ou quando a ação for intentada perante juiz incompetente ${ }^{25}$.

5 - Quando o habeas-corpus foi reconduzido a seus contornos clássicos pela reforma constitucional de 1926, teve imediatamente início a ampla obra que levaria à criação de um instrumento de tutela de liberdades não reconduzíveis à liberdade de locomoção. Muitos foram os projetos legislativos, que acabaram porém melancolicamente com o regime totalitário instituído pelo movimento armado de 1930. Mas o novo instrumento processual foi incluído nos trabalhos preparatórios da constituinte de 1934, com o nome mandado de segurança ${ }^{26}$ e, desde o nascimento, também na modalidade preventiva. A Constituição de 16 de julho acolheu o instituto, no art. 113, n. 33 (conservando o habeas-corpus no n. 23), nas duas modalidades de tutela.

A primeira disciplina legislativa do mandado de segurança só veio à luz em 1936, pela Lei n. 191, de 16 de janeiro. Mas doutrina e jurisprudência haviam considerado a norma constitucional imperativa e auto-aplicável, de modo que o novo e poderoso instrumento de proteção das liberdades foi utilizado antes mesmo da edição da lei, também na perspectiva da suspensão liminar do ato gravoso já praticado, que se considerou implícita ${ }^{27}$.

409.

24. V, por todos, Tourinho Filho, Processo penal, vol. IV, 1980, pág.

25. Sobre a ampla casuística do instituto, v. Pontes de Miranda, História e prática do habeas-corpus, 1979, vol. II, pág. 117 e segs.

26. Foi João Mangabeira que cunhou a denominação, na 20 a reunião $^{\text {a }}$ da Subcomissão para o Anteprojeto constitucional.

27. As primeiras decisões concessivas da segurança remontam ao mês de agosto de 1934: ., por ex., Arch. Jud., n. 31, pág. 419. 
A Carta de 10 de novembro de 1937, embora mantendo - habeas-corpus na dimensão clássica da liberdade de locomoção, suprimiu o mandado de segurança. Mas o instituto continuou a integrar o sistema jurídico brasileiro ao menos na esfera legislativa, mantido que foi pelo Decreto-lei n. 6, de 16 de novembro de 1937, ressalvados os atos do Presidente da República, dos Ministros, Governadores e Interventores (art. 16). Com essa restrição, coerente com o regime totalitário da época, o mandado de segurança teve aplicação também no Estado Novo, até que o Código unitário de 1939 veio regulamentar o mandado de segurança entre os procedimentos especiais (arts. 319 usque 331). A restrição do Decreto-lei n. 6, de 1937, foi mantida no código (art. 319), vindo a ser suprimida somente cinco anos após a restauração do Estado de Direito, graças à Lei n. 1.533, de 31 de dezembro de 1951, ainda em vigor ${ }^{28}$.

Devolvida a dignidade constitucional ao mandado pela Lei Maior de 1946 (art. 141, § 24), na Constituição vigente o instituto é previsto pelo art. $153, \S 21$. Da Constituição retiram-se os princípios fundamentais que regulam o writ: seu campo é determinado por exclusão; deve ter à base um direito liquido e certo, no sentido da desnecessidade de dilação probatória, porquanto os fatos hão de emergir à primeira vista, pelo exame da prova documental; é impetrável somente quanto aos atos da administração pública ou de seus concessionários, entre eles os agentes no exercício de uma competência delegada (como, por ex., os diretores de estabelecimentos de ensino particular). A Constituição, desde a de 1946, não mais se refere à ameaça: mas a ampla fórmula constitucional não exclui a tutela preventiva, expressamente prevista a nível de lei ordinária.

A disciplina legislativa do mandado é dada pela Lei $n$. 1.533 , de 31 de dezembro de 1951, ainda em vigor, com as modificações sucessivas. A ação protege quer os direitos subjetivos, quer os interesses legítimos. Seu autor pode ser tanto a pessoa física como a jurídica. Réu é o Estado, e não a autoridade, muito embora as informações desta correspondam a uma verdadeira contestação. A suspensão liminar do ato gravoso é minuciosamente regulada. $O$ termo de cento e vinte

28. Todavia, desde a época do Estado Novo a exceção era contida pela jurisprudência: entendiam-se imunes ao mandado certas autoridades, mas não aquelas que determinassem a execução do ato ilegal; assim, paradoxalmente, um instituto destinado à tutela das liberdades públicas acabou consolidando-se em um regime autoritário, porquanto não se curvou à constrição que lhe havia sido imposta quase ao nascer. 
dias para a impetração é de decadência. A sentença pode ser condenatória, constitutiva ou meramente declaratória. A coisa julgada material só ocorre na hipótese de um juízo conclusivo de mérito, pelo que pode o autor recorrer às vias ordinárias se a segurança for rejeitada por inadmissível ou por incerteza sobre os fatos. A ação não pode ser proposta enquanto não se esgotarem as vias administrativas, a menos que o recurso administrativo não tenha efeito suspensivo ou exija caução. É expressamente prevista a segurança preventiva ${ }^{29}$.

A jurisprudência construiu proficuamente em torno do mandado de segurança, dando à lei interpretação ainda mais aberta, como no caso do writ contra ato jurisdicional, inclusive sentença, quando o recurso previsto pelos códigos de processo (civil e penal) não tenha efeito suspensivo ${ }^{30}$.

6 - $\mathrm{O}$ perigo iminente ou a ameaça de violência ou coação à liberdade de locomoção são as fórmulas constitucionais e legais que, desde 1871, autorizam o habeas-corpus preventivo. Hoje a Constituição prefere falar de ameaça; e o Código de Processo Penal, no art. $660, \S 4 .^{\circ}$, prescreve: "Se a ordem de habeas-corpus for concedida para evitar ameaça de violência ou coação ilegal, dar-se-á ao paciente salvo-conduto assinado pelo juiz". No art. 647, repetindo a fórmula da Carta de 1937, afirma-se: "Dar-se-á habeas-corpus sempre que alguém sofrer ou se achar na iminência de sofrer violência ou coação ilegal em sua liberdade de ir e vir, salvo nos casos de punição disciplinar".

Como foi justamente salientado, o problema central das ações preventivas é o interesse de agir ${ }^{31}$. E o primeiro requisito do interesse de agir é a necessidade do uso das vias jurisdicionais. Na Alemanha, a expressão "necessidade de tutela jurídica" é freqüentemente usada para indicar essa conđ̃ição da ação ${ }^{32}$.

Para quem, como nós, examina os institutos processuais penais da plataforma da teoria geral do processo ${ }^{33}$, a questão

29. Sobre os aspectos processuais do instituto, v., por todos, BARBI, Do mandado de segurança, 3. a ed., 1976, pág. 65 e segs.

30. Para o mandado de segurança contra ato jurisdicional, v. WAtANABE, mandado de segurança contra atos judiciais, 1980, pág. 93 e segs.

31. Michels, L'azione preventiva cit., pág. 202/5; Grossen, L'azione in prevenzione al di fuori dei giudizi immobiliari, em Riv. dir. proc., pág. 417 e segs. Entre nós, cf. BARBI, op. cit., pág. 105.

32. Assim, por ex., Schonze e Lent: v. Allorio, Bisogno di tutela giuridica?, em Jus, I, 1954.

33. V., especialmente, da autora, O processo em sua unidade, 1978. 
de fundo do habeas-corpus preventivo é o interesse-necessidade ${ }^{34}$.

$O$ requisito da necessidade concreta de jurisdição significa que o direito de ação não pode ser exercido, enquanto as forças do direito material ainda não se mostrem incapazes de extinguir a situação de lide ${ }^{35}$.

Ora, para que a ameaça possa configurar o interesse de agir, deve ela ser séria, grave, e não pode ser examinada no enfoque de seu efeito subjetivo. O perigo de dano jurídico, a ameaça de lesão, significam, objetivamente, sinais inequívocos da iminência desta. A ameaça deve ser objetiva e atual, como se afirmou na Declaração do Congresso de Bruxelas ${ }^{36}$. Será objetiva quando real, ou seja traduzida por atos e fatos, e não por meras suposições; e será atual quando exista no momento em que a tutela é pedida ${ }^{37}$. É assim que deve ser interpretado o art. 654, § $10^{\circ}, b$, do CPP ("A petição de habeas-corpus conterá: ... b) a declação da espécie de constrangimento ou em caso de simples ameaça de coação as razões em que se funda o seu temor") ${ }^{38}$.

É exatamente essa a linha da jurisprudência quanto ao habeas-corpus preventivo ${ }^{39}$, observando-se apenas que não se exige a prova plena da ameaça de dano, sendo suficientes fundadas razões ou indicios veementes ${ }^{40}$.

O campo de abrangência do habeas-corpus preventivo é o mais amplo possível, encontrando aplicação em todos os casos do art. $648 \mathrm{CPP}$, e mesmo nos não compreendidos na enume-

34. Com relação à ação penal condenatória, o interesse de agir, afirmamos (As condições da ação penal, 1977, pág. 103 e segs.), é inerente ao direito de ação, implícito na acusação, porquanto o Estado não pode impor a pena senão pelas vias jurisdicionais: a necessária utilização das vias processuais, na ação condenatória, retira do processo criminal a aplicabilidade do critério de exigibilidade, entendida como ausência de impedimento jurídico para a satisfação voluntária da pretensão. Diversa é a situação no habeas-corpus, ação do indivíduo contra o Estado, para obter a tutela de sua liberdade pessoal.

35. Dinamarco, Execução civil, 1973, n. 20.

36. V. retro, nota 11.

37. Assim, BarBi, op. cit., págs. 107/8.

38. Ver, sobre o justo temor, como reflexo subjetivo da ameaça, adiante, n. 7 .

39. V., entre tantas, a decisão do Tribunal de Justiça de São Paulo, em Rev. Tribs., n. 528, pág. 308 e segs. Outra jurisprudência em Pontes DE Mrranda, op. cit., vol. II, págs. 17/19.

40. Pontes de Miranda, op. e loc. cit., com jurisprudência. 
ração legal ${ }^{41}$. Pense-se no campo extrapenal, quando a ameaça de lesão à liberdade de locomoção provenha do juiz civil, nos casos de prisão por alimentos ou do depositário infiel (art. 153, § 17 da Constituição).

Como já vimos, a doutrina dominante considera o habeas-corpus uma ação, e não um recurso, embora como recurso venha rotulado no Código de Processo Penal. É verdade que em alguns casos - como no de manifesta nulidade do processo - habeas-corpus exerce função equivalente à de um recurso. Mas, no sistema brasileiro, o recurso é sempre destinado à revisão de ato jurisdicional ainda não passado em julgado, sendo sua função, exatamente, a de evitar a formação da coisa julgada. Por isso, mesmo no caso de nulidade, não existindo qualquer termo preclusivo para a interposicão do habeas-corpus, o instituto não pode ser incluído entre o rol dos recursos ${ }^{42}$.

Objetou-se que o writ pode ser concedido de ofício pelo juiz ou pelo tribunal, sem provocação, quando, no curso do processo, o órgão jurisdicional verifique a existência da coação ilegal ou de sua ameaça (art. 654, § 2. ${ }^{\circ}, \mathrm{CPP}$ ). Mas mesmo aqui, se bem se observa o fenômeno da ação, em seu aspecto analítico, verifica-se a existência desta: ainda quando o juiz independe da iniciativa da parte para instaurar o processo, uma vez iniciado a parte é investida de poderes e faculdades na relação processual, em cujo exercício estimula o órgão jurisdicional a levar adiante o procedimento. $\mathrm{E}$ isto também é direito de ação ${ }^{43}$.

Ação, portanto, e de conhecimento, porque já vimos que o habeas-corpus preventivo não pertence à tutela cautelar. 0 conhecimento é sempre completo e leva a um provimento definitivo.

Se é verdade que o habeas-corpus sucessivo pode assumir ora as vestes de uma ação constitutiva (como no caso de nulidade, quando já exista uma sentença passada em julgado ${ }^{44}$ ), ora as de uma ação meramente declaratória (como quando,

41. Pretendeu-se excluir, do âmbito do habeas-corpus preventivo, a hipótese de excesso de pena: mas PONTeS DE MIRANDA salientou a aplicabilidade da tutela preventiva no caso de ordem de prisão por tempo superior ao da pena. (op. cit., pág. 17).

42. Cf. Tourinho Filho, Processo penal, vol. IV, 1979, pág. 408.

43. Essa idéia, já avançada em As garantias constitucionais do direito de ação, 1973, pág. 156 e segs., foi por nós retomada, nos termos supramencionados, quanto à execução penal: v. Cintra, Grinover \& Dinamarco, Teoria geral do processo, $3 .^{\text {a }}$ ed., 1981, pág. 279.

44. Nesse caso, foi exatamente salientada a função de revisão dó habeas-corpus: TouRinho Filho, op. cit., pág. 409. 
por falta de justa causa - ou fumus boni iuris -, se declara inexistente o poder - dever punitivo e, conseqüentemente, se extingue a ação penal em curso ou se arquiva o inquérito policial), parece evidente que o habeas-corpus preventivo terá sempre caráter de ação meramente declaratória, no sentido de que a sentença conterá sempre e tão-só uma declaração quanto à existência do direito de liberdade pessoal, não acompanhada de outros efeitos sancionatórios. Nesse sentido já se manifestou JosÉ FrEDERICO MARQUeS ${ }^{45}$ e assim escrevemos, desde a primeira edição da Teoria geral do processo ${ }^{46}$.

De natureza cautelar, ao contrário, é a concessão liminar do habeas-corpus que, embora não expressamente autorizada pela lei, se esboça em doutrina ${ }^{47}$, na esteira da concessão in limine do mandado de segurança. A liminar do habeas-corpus, quer em sua modalidade preventiva, quer na sucessiva, insere-se entre os provimentos cautelares que CALAMANDREI classificou como antecipatórios de um provimento decisório definitivo ${ }^{48}$.

7. Ao mandado de segurança preventido referiu-se a Constituição de 1934, que o criou, falando de ameaça. A Lei n. ${ }^{\circ} 191$, de 16 de janeiro de 1936, mantida pelo Decreto-Lei . $^{\circ}$ 6, de 16 de novembro de 1937, ateve-se à mesma terminologia. Não inovou o Código de Processo Civil de 1939, mas a Lei n. ${ }^{\circ}$ 1.533, de 31 de dezembro de 1951 - ainda em vigor - introduziu um conceito novo no art. 1. $0^{\circ}$ "Conceder-se-á mandado de segurança para proteger direito líquido e certo não amparado por habeas-corpus, sempre que, ilegalmente, ou com abuso do poder, alguém sofrer violação ou houver justo receio de sofrê-la por parte de autoridade, seja de que categoria for e sejam quais forem as funções que exerça".

45. Marques, Elementos de direito processual penal, vol. I, 1961, pág. $324 / 325$, onde se fala em uma ação positiva de declaração destinada a reconhecer o direito penal de liberdade, lembrando-se a ação declaratória utilizada nos Estados Unidos da América para impedir a instauração do processo penal (cf. Goldschmidt, La sentencia declarativa, em Rev. Der. Procesal, 1943, págs. 400/403).

46. Cintra, Grinover \& Dinamarco, op. cit., $1 .^{\mathrm{a}}$ ed., 1976, pág. 267 (agora em $3 .^{\text {a }}$ ed., pág. 272). Sobre a sentença mandamental que, segundo certa doutrina, configurar-se-ia no habeas-corpus - como no mandado de segurança -, v. infra, n. 7.

47. Tornaghi, Curso de processo penal, 1980, págs. $391 / 2$.

48. Calamandrer, Introduzione cit., pág. 38 e segs. V. também infra, n. 7 . 
Foi assim que a expressão justo receio substituiu a de ameaça, inserindo-se comodamente na ampla fórmula constitucional.

Mas o termo justo receio tem sido criticado por seu cunho nitidamente subjetivo. O que importa, afirmou-se, não é o receio do autor, que varia consoante a sua sensibilidade. $\mathrm{E} o$ que se deve qualificar não é o receio, mas a ameaça, que constitui o seu elemento objetivo. 0 receio é o reflexo subjetivo da ameaça, e não um elemento para definição daquela ${ }^{49}$.

Embora a expressão justo receio seja tradicional no direito pátrio ${ }^{50}$, é pacífico que deve ele ter uma causa, que é a ameaça : e a ameaça há de ser séria, grave e não subjetiva ${ }^{51}$.

Assim, tanto quanto para o habeas-corpus, o interesse de agir - questão nodal da tutela preventiva ${ }^{52}$ - configura-se, nessa modalidade de mandado de segurança, pela ameaça objetiva e atual, que corresponda a sinais inequívocos da iminência do prejuízo jurídico.

Nessa perspectiva, foi destacado o amplo campo de atuação que o mandado preventivo poderia ter contra a lei inconstitucional ${ }^{53}$ : embora um princípio clássico do ordenamento afirme que não se pode atacar por via de mandado de segurança - ou por outra via judiciária - a lei em tese ${ }^{54}$, no caso de leis auto-executáveis já se admite a possibilidade de subtrair o autor dos efeitos da lei inconstitucional, posto que a lei não ataque a esta diretamente ${ }^{55}$. Quanto ao mandado de segurança preventivo, o discurso amplia-se: após a publicação da lei inconstitucional, afirmou-se, e uma vez tomadas as providências necessárias à sua execução, o titular do direito ameaçado por tais providências pode ir a juízo para impedir que a lesão se consume. A ameaça será examinada na ótica dos requisitos supramencionados. E a sentença, em caso de afirmação do direito do autor, vai atacar aquelas providências, e não a lei: de modo

49. BARBI, Mandado de segurança, cit., págs. 106/7.

50. Os códigos processuais dos Éstados federativos, antes do código unitário de 1939, referiam-se com certa freqüência ao justo receio. A expressão foi adotada pelo código revogado e, na legislação vigente, é encontrada não só na lei do mandado de segurança, como também no Código de Processo Civil de 1973, no art. 932, que regula o interdito proibitório.

51. Assim Americlano, nos Comentários ao CPC, vol. II, 2. ed., págs. $190 / 191$

52. V. supra, n. 6 .

53. BARBI, op. cit., pág. 108.

54. Súmula n. 266 do STF.

55. V., por todos, BARBI, op. cit., pág. 139 e segs. 
que, nesses casos, a autoridade coatora é a que tomou as providências necessárias à execução da lei, e não a que legislou ${ }^{56}$.

Sobre a natureza do mandado de segurança não se discute: trata-se de uma ação que tende, conforme o caso, à mera declaração, à condenação ou à constituição de um novo estado ou relação jurídica ${ }^{57}$. Alguns autores falam em sentença mandamental, porque a ordem - assim como para o habeas-corpus - é dirigida a uma autoridade ${ }^{58}$. Isso não elimina, contudo, a carga preponderante ora de condenação, ora de constitutividade, ora de mera declaração ${ }^{59}$. 0 mandado de segurança preventivo, tanto quanto o habeas-corpus da mesma natureza, visa sempre a uma sentença meramente declaratória ${ }^{60}$.

Lembre-se que a lei prevê a antecipação da suspensão dos efeitos do ato coativo ou da ameaça de lesão, por intermédio da concessão liminar do mandado (art. $7 .^{\circ}$, II, da Lei n..$^{\circ} 1.533$ ). Essa hipótese, quer para o mandado de segurança preventivo, quer para o sucessivo, enquadra-se entre os provimentos cautelares que CALAMANDREI classificou como antecipatórios de provimentos decisórios, consistindo in una decisione anticipata e provvisoria del merito, destinata a durare fino a che a questo regolamento provvisorio del rapporto controverso si sovrapporrà il regolamento stabilmente conseguibile attraverso il più lento processo ordinario ${ }^{61}$.

Não se discute, entre nós, sobre a natureza cautelar da concessão liminar ${ }^{62}$, firme restando, porém, a natureza definitiva da tutela preventiva.

Nem se confundem segurança preventiva e segurança normativa. A primeira conduz a uma sentença de mérito cuja imutabilidade é contida nos limites subjetivos e objetivos da coisa julgada. A segunda seria aquela que pudesse estabelecer uma regra de conduta para casos futuros, indeterminados. No ordenamento pátrio inexiste a segurança normativa; ainda que

56. BARBr, op. cit., págs. 108/109.

57. V, por todos, BARBI, op. cit., 244 e segs.

58. Pontes DE MirandA, Tratado das ações, Tomo VI, Ações mandamentais, 1976. $270 / 271$.

59. V. Cintra, Grinover \& Dinamarco, Teoria geral cit., $3 .^{a}$ ed., págs.

60. V. supra, n. ${ }^{\circ} 6$.

61. CalamandRei, Introduzione cit., pág. 38 e segs.

62. V, por todos, BARBI, op. cit., págs. 200/201.

63. Por todos, Lopes Meirelles, Mandado de Segurança, 1979, pág. 56. 
a ilegalidade se repita em casos idênticos, será sempre necessária uma nova decisão para cada caso, porque os efeitos da sentença anterior se restringem ao caso concreto, entre as mesmas partes. $\mathrm{O}$ mandado de segurança invalida o ato impugnado, mas deixa intacta a norma considerada ilegal ou inconstitucional ${ }^{63}$ A coisa julgada opera, na sentença do mandado de segurança, como em qualquer outra sentença, com a única diferença de que, em caso de incerteza sobre os fatos, a sentença que nega a ordem não impede o uso das vias ordinárias ${ }^{64}$.

64. Súmula n. 304 do STF. Cf. BARBI, op. cit., pág. 255 e segs. 